\title{
PENGEMBANGAN WISATA PANTAI SO PANCALA DALAM UPAYA MENINGKATKAN TS (TOURISM SECTOR) DAN ES (ECONOMIC SECTOR) DI KELURAHAN KOLO KOTA BIMA
}

\author{
Aliah Pratiwi' ${ }^{1)}$ | Nurul Huda ${ }^{2)} \mid$ Al Akbar ${ }^{3)}$ |Mukhlis $^{4)}$ | Nafisah Nurulrahmatiah ${ }^{5)}$ \\ 1,2,3,4,5) STIE BIMA \\ aliahpratiwi@ymail.com | nurulhuda.stiebima@gmail.com | akbar.rege97@gmail.com | \\ emukhlis@gmail.com | nafisahrachmatia@gmail.com
}

\begin{abstract}
Abstrak: Kelurahan Kolo, Kota Bima, NTB, memiliki potensi wisata yang cukup baik, tetapi masyarakat setempat masih belum menyadari hal ini. Tujuan kegiatan Pengabdian Kepada Masyarakat ini adalah (1) pengembangan potensi wisata, (2) pemberdayaan masyarakat, dan (3) membuat kelengkapan sarana pendukung wisata di So Pancala. Metode yang digunakan adalah analisis daya tarik objek wisata, analisis pendukung pariwisata, dan analisis masyarakat setempat. Pengabdian ini dilaksanakan dengan mitra warga dan pokdarwis di Kelurahan Kolo Kota Bima. Hasil yang diperoleh dari pengabdian ini adalah optimalisasi potensi wisata dengan dibuatnya sarana pendukung seperti tugu penanda lokasi pantai, jembatan kayu, ayunan kayu, tempat duduk, tempat sampah dan penambahan spot untuk swafoto di sekitar pantai So Pancala. Hasil dari kegiatan ini adalah kesadaran masyarakat dan Pokdarwis lebih meningkat dan beberapa sarana pendukung bagi wisatawan sudah tersedia, hal ini akan memberikan dampak langsung bagi peningkatan jumlah kunjungan wisatawan dan peningkatan pendapatan ekonomi masyarakat.
\end{abstract}

Kata Kunci: Pengembangan Wisata Pantai, Tourism Sector, Economic Sector

\section{Pendahuluan}

Pariwisata di Indonesia menurut UU Kepariwisataan No. 9 tahun 1990 pasal 1 (5) adalah segala sesuatu yang berhubungan dengan wisata serta usaha-usaha yang terkait di bidangnya. Pada dasarnya Indonesia umumnya memiliki kekayaan bahari yang berlimpah, yang mencakup kehidupan sekitar 28 ribu species flora, 350 species fauna, 110 ribu species mikroba, serta sekitar 600 species terumbu karang. Keanekaragaman terumbu karang di Indonesia mencapai 600 species dari 400 genera, jauh lebih kaya dari yang dikandung Laut Merah yang hanya memiliki 40 species. Laut Indonesia memiliki ratusan titik harta karun. Benda-benda berharga itu berasal dari muatan kapal yang tenggelam. Bagi Indonesia wilayah pesisir memiliki arti strategis karena merupakan wilayah peralihan antara ekosistem darat dan laut, serta memiliki potensi sumberdaya alam dan jasajasa lingkungan yang sangat kaya. Kekayaan sumberdaya tersebut menimbulkan daya tarik bagi berbagai pihak untuk memanfaatkan sumberdayanya dan berbagai instansi untuk meregulasi pemanfaatannya. Pariwisata merupakan salah satu sektor yang dianggap memiliki peranan penting dalam pembangunan suatu negara, di mana pariwisata secara langsung dapat memberikan kontribusi lebih pada pendapatan daerah di mana objek wisata tersebut berada. Sektor pariwisata dapat dijadikan sebagai salah satu sektor unggulan dalam perolehan devisa, penciptaan lapangan kerja maupun dalam pengentasan kemiskinan (Pitana \& Diarta, 2009).

Nusa Tenggara Barat (NTB) adalah salah satu provinsi yang memiliki potensi pariwisata yang sangat baik, tidak berbeda jauh dengan provinsi Bali. NTB memiliki keanekaragaman kekayaan alam, budaya dan adat istiadat. Kesemuanya itu juga merupakan potensi wisata yang menjanjikan. Setiap kabupaten atau kota di NTB memiliki potensi keunikan objek wisata alam, budaya dan minat khusus. Kota Bima adalah salah satu Kota yang berada di provinsi NTB yang juga mempunyai potensi di bidang pariwisata. Sebagai salah satu kelurahan yang memiliki potensi pariwisata pantai di Kota Bima, Kelurahan Kolo masuk menjadi salah satu kelurahan yang berpotensi untuk di kembangkan keberadaan 
pariwisatanya. Pantai Kolo menawarkan pesona pantai yang menawan terbentang hamparan pasir sepanjang lokasi wisata pantai $\geq 2 \mathrm{~km}$ dan terbagi dalam beberapa spot pantai, mulai dari pantai So Buntu sampai pantai So Numbe dimana sebagian pantai sudah di kelola dan ada beberapa pantai yang belum di kelola secara maksimal. Bila air laut surut, kita dapat melihat lansgung terumbu karang yang berada di sekitaran pantai. Selain itu terdapat lokasi Diving yang menarik di lokasi wisata pantai.

Pantai So Pancala merupakan salah satu objek wisata baru di Kelurahan Kolo Kota Bima Provinsi NTB yang terkenal dengan air lautnya yang bersih dan panorama pantai yang indah. Pantai So Pancala merupakan bagian dari beberapa pantai lain yang berada di sepanjang pantai di Kelurahan Kolo Kota Bima dan kini telah menjadi salah satu destinasi wisata yang memiliki tingkat kunjungan yang terus mengalami peningkatan. Tetapi karena kurangnya fasilitas dan sarana yang mendukung keberadaan pantai So Pancala masih kurang di minati di bandingkan dengan pantai-pantai lain di sebelahnya yang sudah lebih dulu memiliki sarana dan fasilitas yang lebih lengkap.

Berdasarkan observasi yang dilakukan di Pantai So Pancala, sarana dan prasana yang tersedia masih sangat minim, wisatawan yang berkunjung apabila membutuhkan sarana seperti MCK, tempat duduk dan lainnya masih perlu memanfaatkan sarana di pantai yang dekat dengan So Pancala. Bahkan keberadaan di pinggir pantai masih tidak terurus, terlihat sampah dan semak-semak yang mungkin tidak pernah di bersihkan. Masyarakat hanya memanfaatkan pantainya untuk mandi. Tidak tersedianya tempat sampah di sekitar objek wisata tersebut, membuat pengunjung membuat sampah sembarangan sehingga keadaan di pinggir pantai masih di penuhi sampah-sampah sisa makanan dan minumam. Di pantai So Pancala sudah tersedia lapak penjual makanan yang hanya menyediakan beberapa jenis makanan ringan dan kelapa muda. Selain itu promosi yang dilakukan oleh pemerintah Kota Bima terutama pemerintah kelurahan masih belum maksimal karena sampai saat ini informasi yang diperoleh mengenai Pantai masih diperoleh dari media mulut ke mulut dan media sosial dari pengunjung sebelumnya.

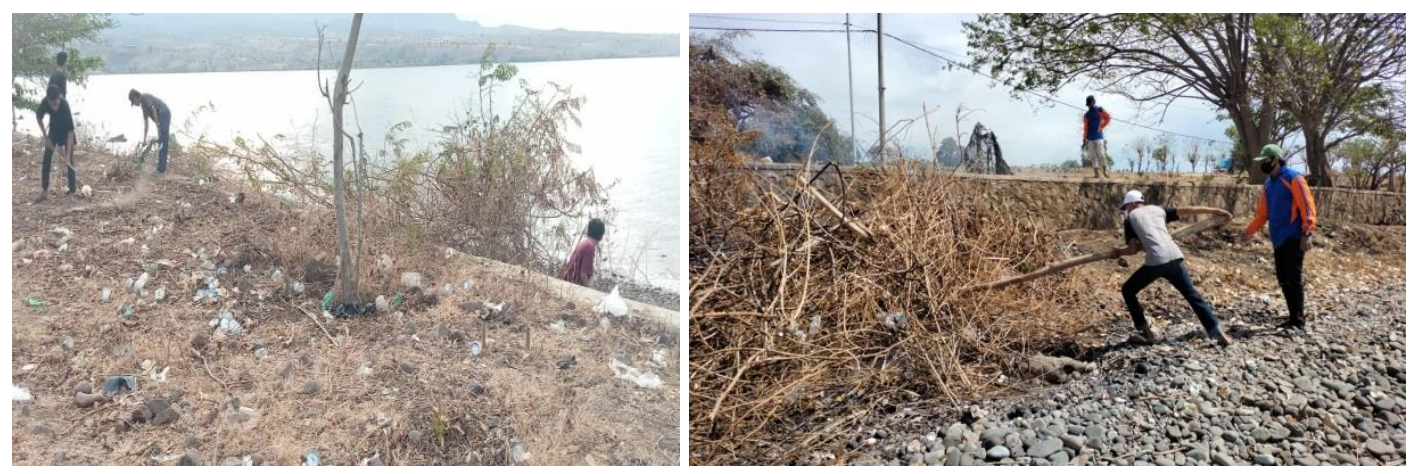

Gambar 1 Kondisi di pinggir pantai sebelum di lakukan proses pengembangan

Aktifitas di tempat pariwisata sepanjang pantai di kelurahan kolo selalu terlihat ramai, terutama di hari-hari libur. Bahkan banyak dari pengunjung yang tidak kebagian tempat, berdasarkan data pengunjung dalam seminggu kurang lebih 1.000 orang berunjung di pantai kolo yang tempatnya di bagi dalam beberapa pantai. Biasanya pengunjung yang datang lebih banyak dari wilayah Kota Bima saja karena lokasi Wisata Pantai berada di wilayah kota. Pengunjung wisata pantai mulai dari anak-anak, remaja, pemuda, orang tua hinga kakek-nenek menghabiskan waktu berlibur di wisata sepanjang pantai sambil menikmati ikan bakar, es kelapa atau makan-makanan lain yang di jual sekitaran pantai. Bahkan saat ini pemerintah kelurahan setempat sedang gencar-gencarnya memanfaatkan produk lokal untuk di pasarkan di sekitar pantai dan sebagai wujud dari keseriusan pemerintah kota maupun kelurahan sudah di sediakan pasar produk lokal di sekitar pantai sebagai tempat memasarkan produk-produk lokal yang di produksi sendiri oleh warga setempat.

Program pemberdayaan masyarakat dengan pengembangan TS (Tourism Sector) Dan ES (Economic Sector) yang berbasis pada sektor pariwisata dan sektor ekonomi. Sektor pariwisata mampu menghidupkan ekonomi masyarakat di sekitarnya. Sektor pariwisata juga diposisikan sebagai sarana penting dalam rangka memperkenalkan budaya dan keindahan alam daerah terkait. Sektor 
pariwisata merupakan sumber pendapatan yang dapat terus diperbaharui dan diremajakan, bentuk peremajaan daerah wisata ini dapat berupa renovasi, dan perawatan secara teratur. Sektor ekonomi dalam sektor pariwisata merupakan mata rantai ekonomi yang panjang (Multiplier effect), mulai dari biro perjalanan, jasa pengangkutan, perhotelan, restoran, kegiatan pemanduan, kerajinan rakyat, pemeliharaan objek wisata dan lain sebagainya. Selanjutnya dalam sektor ekonomi juga akan membutuhkan hasil pertanian, peternakan, perikanan serta sejumlah tenaga kerja juga dapat diserap didalamnya sebagai pendukung keberhasilan mata rantai tersebut.

Mayoritas warga sangat antusias dalam pengembangan wisata pantai di sepanjang pantai di Kolo, hal ini menjadi tantangan sekaligus peluang bagi terealisasikannya program tersebut ke depannya. Jika lingkungan utamanya didaerah pesisir rusak atau tidak terawat tentu hal itu akan mempengaruhi dalam sektor wisata juga, tidak akan ada wisatawan yang ingin berkunjung jika kondisi pantai tidak di tata atau di kelola dengan baik. Secara ekonomis, wisata pantai tentu dapat menjadi salah satu sumber mata pencaharian warga kolo meskipun banyak di antaranya yang menjadi nelayan. Berdirinya wisata pantai di sepanjang pantai kolo terutama So Pancala ini sangat berkontribusi besar bagi peningkatan ekonomi warga, utamanya mereka yang berdekatan dengan wisata pantai So Pancala. Dari sektor ekonomi diharapkan keberadaan pantai So Pancala dapat memancing masyarakat untuk menghasilkan kerajinan atau produk lokal yang memiliki nilai ekonomis serta dapat menggeliatkan UMKM dan industri rumahan, misal: pengolahan ikan kering, pengolahan krupuk ikan dan sebagainya.

Menurut undang-undang Nomor 23 Tahun 2014 tentang pemerintahan daerah, termuat sistem penyelenggaraan pemerintah daerah diarahkan untuk mempercepat terwujudnya kesejahteraan masyarakat dengan meningkatkan pelayanan, pemberdayaan dan peran masyarakat (Undang-Undang Otonomi Daerah, 2014). Dengan adanya kegiatan ini diharapkan terjadi perubahan dalam masyarakat dan menimbulkan kesadaran untuk menjaga dan melestarikan potensi wisata di daerah tersebut (Aboe \& Ibrahim, 2019).

Program kegiatan Pengabdian Kepada Masyarakat Oleh dosen dan mahasiswa KKN STIE BIMA Tahun 2021 mencoba melakukan mitra dengan masyarakat Kolo Kota Bima dalam rangka pengembangan atau penataan kembali wisata pantai So Pancala yang selama ini tidak terurus. Program Pengabdian Kepada Masyarakat yang dilakukan di Kelurahan Kolo Kota Bima secara tidak langsung nantinya akan membantu perekonomian masyarakat di sekitar pantai sehingga dapat menjadi salah satu sumber pendapatan.

Target yang diharapkan dalam kegiatan ini adalah sebagai berikut :

1. Pengembangan TS (tourism sector) yaitu sektor yang potensial untuk dikembangkan sebagai salah satu sumber pendapatan daerah. Program pengembangan dan pendayagunaan sumber daya dan potensi pariwisata daerah diharapkan dapat memberikan sumbangan bagi pembangunan ekonomi. Dalam hal ini diharapkan dengan adanya pengembangan wisata akan meningkatkan jumlah kunjungan wisatawan ke pantai So pancala

2. Pengembangan ES (economic sector) yaitu dengan adanya sektor pariwisata maka akan menyebabkan perekonomian masyarakat lokal menggeliat dan menjadi stimulus investasi sehingga menyebabkam sektor ekonomi akan berkembang. Dengan di kembangkannya wisata pantai, secara langsung akan memberikan efek yang besar bagi pengembangan ekonomi di suatu daerah. Misalnya dengan memanfaatkan UMKM yang ada.

\section{$\underline{\text { Realisasi Kegiatan }}$}

Lokasi pelaksanaan kegiatan yaitu di Kelurahan Kolo Kota Bima NTB, waktu perlaksanaan dilaksanakan selama bulan September 2021. Pelaksana kegiatan pengabdian adalah mahasiswa KKN STIE Bima bersama para dosen dan dibantu oleh masyarakat sekitar pantai. Adapun tahapan-tahapan yang dilakukan dalam proses pengabdian adalah :

a. Analisis daya tarik obyek wisata 
Analisis yang dilakukan meliputi (1) analisis kondisi lingkungan; (2) analisis kemudahan akses obyek wisata. Analisis lapangan menghasilkan beberapa temuan sebagai berikut:

1. Lokasi Pantai So Pancala

Lokasi pantai So Pancala sangatlah strategis karena berada langsung di pinggir jalan utama. Masyarakat yang berkunjung dapat langsung menyimpan atau memarkir kendaraannya tepat di pinggir pantai tanpa perlu berjalan untuk sampai ke lokasi. Selain itu Pantai So Pancala juga tepat berada di sebelah pantai-pantai yang lebih dulu di kenal masyarakat, sehingga dapat di simpulkan dari segi lokasi sangatlah strategis untuk di kembangkan. Kondisi alam yang indah dapat menjadi nilai tambah bagi wisatawan yang ingin berwisata dan mencari ketenangan atau yang memiliki motivasi psikis/spiritual (Suherlan, 2014)

2. Jalan menuju Pantai So Pancala

Karena Pantai So Pancala berada di ujung Utara wilayah Kota Bima, akses jalan ke pantai ini sudah sangat baik, jika kita memulai perjalanan dari Kota Bima kita akan melewati jalan beraspal dengan melewati sisi gunung dan langsung menikmati keindahan pantai di sepanjang perjalanan menuju lokasi.

3. Analisis Masyarakat

Pada analisis ini sudah di temukan adanya Kelompok Sadar Wisata (Pokdarwis) di kelurahan kolo, tetapi keberadaan mereka belum di maksimalkan dengan baik. Sebagian besar masyarakat bermatapencaharian sebagai petani jagung dan Nelayan sedangkan para ibu adalah ibu rumah tangga. Meskipun demikian, masyarakat sekitar adalah masyarakat yang sangat terbuka dalam menerima masukan. Warga terutama Pokdarwis juga merasa perlu adanya pengembangan wisata Pantai So Pancala agar pantai ini dapat di kenal oleh masayarak luas seperti pantai-pantai yang sudah lebih dulu di kenal saat ini. Berdasarkan hasil analisis ini maka mitra utama dari kegiatan ini adalah warga Kelurahan Kolo Kota Bima.

\section{Hasil}

Berdasarkan hasil analisis lapangan menghasilkan beberapa program yang telah dilakukan oleh Dosen dan mahasiswa KKN STIE Bima bersama mitra dalam kegiatan Pengabdian Kepada Masyarakat (PKM) ini antara lain:

1. Pembersihan sampah dan semak-semak yang sangat tidak terawat di sekitaran pantai So Pancala

2. Pembuatan sarana yang mendukung di sekitaran pantai So Pancala, Misalnya pembuatan Jembatan dari kayu, Tugu penanda pantai, tempat duduk, Ayunan di pinggir pantai, spot untuk swafoto dan pengadaan tempat sampah di sekitar pantai agar lebih menarik wisatawan

3. Peresmian langsung oleh perwakilan Dinas Pariwisata, Pokdarwis dan Bapak Lurah Kolo

Berikut adalah hasil pelaksanaan program Pengabdian Kepada Masyarakat (PKM) dalam rangka peningkatan potensi wisata pantai So Pancala.

Proses Pembersihan semak-semak, sampah serta penyediaan material untuk melengkapi sarana di sekitar pantai di lakukan secara bersama-sama oleh dosen, mahasiswa KKN dan bantuan warga sekitar terutama pokdarwis. 

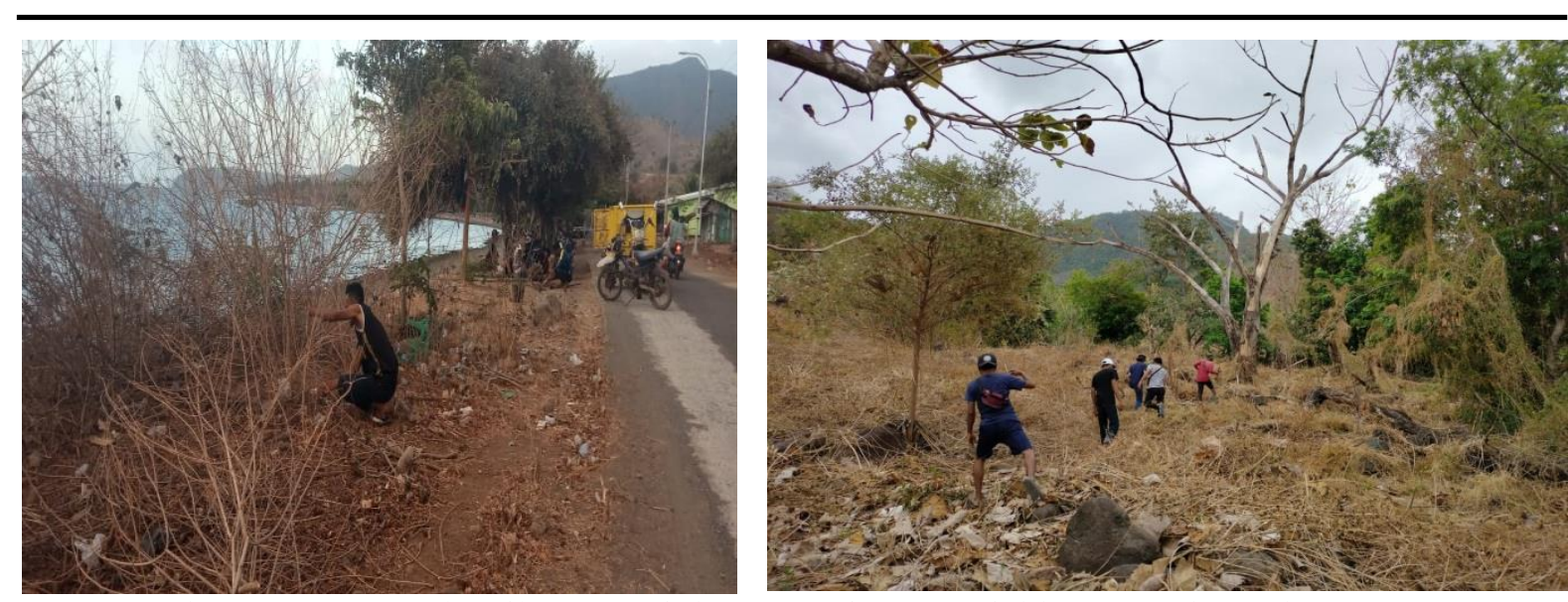

Gambar 2 proses pembersihan pantai dan pencarian material kayu untuk pembuatan sarana pendukung

Kemudian setelah di lakukan pembersihan sekitar pantai dan pencarian material kayu untuk penunjang sarana, tim PKM bersama warga sekitar melakukan proses pembuatan sarana penunjang di sekitar pantai. Mulai dari pembuatan tugu, tempat duduk, jembatan, ayunan, tempat sampah dan spot untuk swafoto.

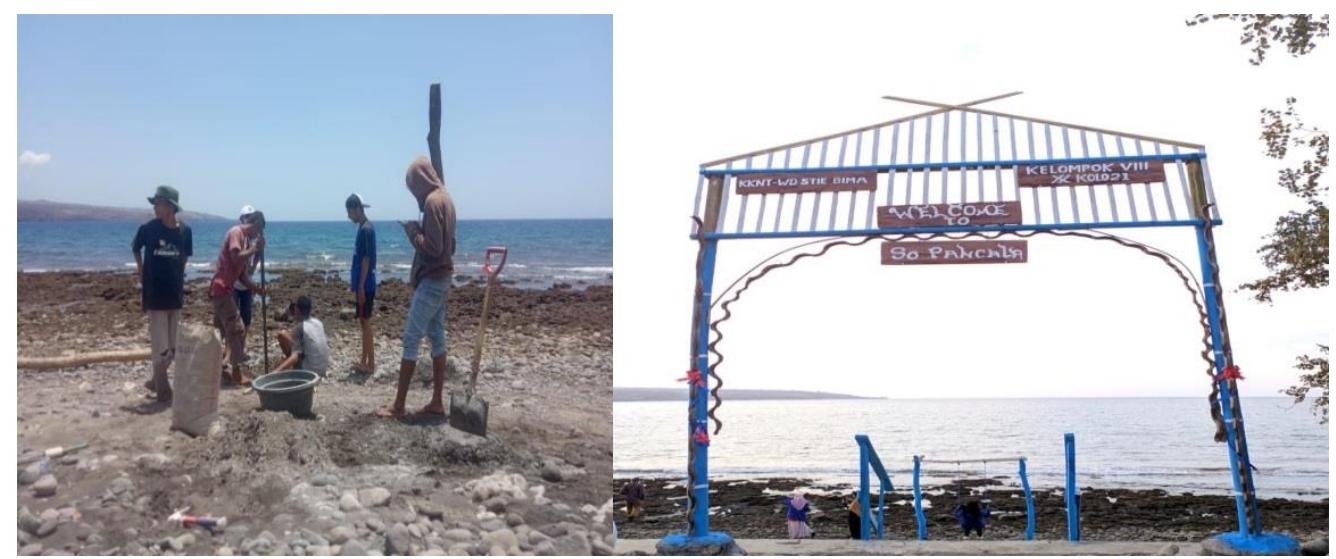

Gambar 3 proses pembuatan beberapa sarana pendukung
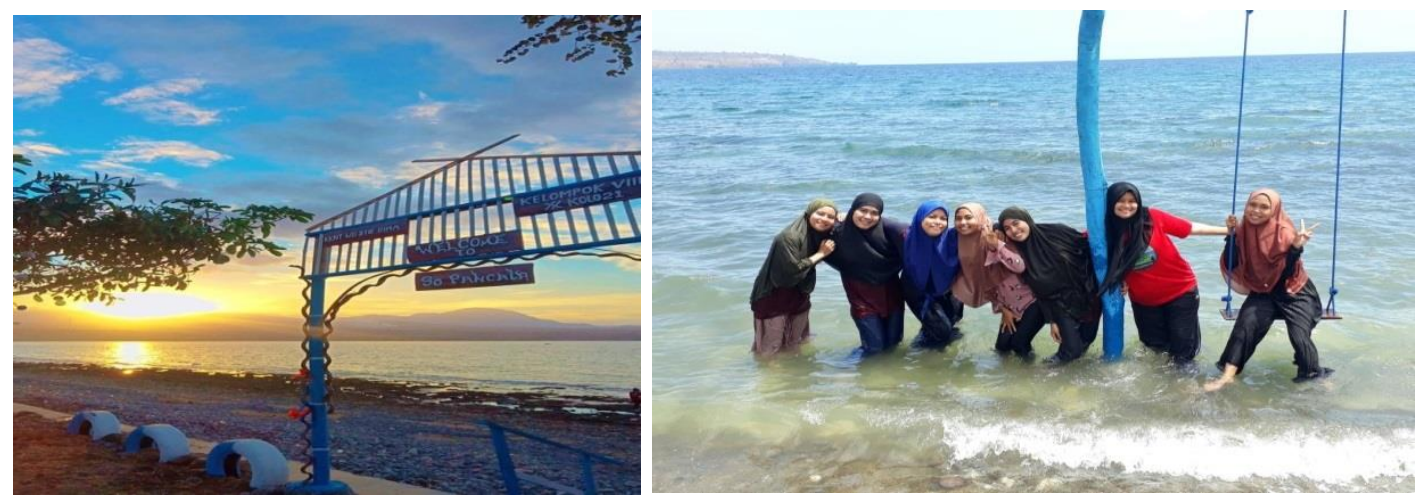

Gambar 4 Pemandangan di lokasi pantai saat pagi dan sore hari

Pengembangan wisata pantai di So Pancala selain di apresiasi dan di dukung penuh oleh warga dan jajaran pemerintahan kelurahan baik dari warga, kelompok pemuda, pokdarwis dan semua elemen masyarakat, pengembangan wisata juga di apresiasi oleh Dinas terkait di Kota Bima. Saat peresmian, hadir langsung perwakilan dari Dinas Pariwisata untuk meresmikan tempat wisata So Pancala, hal ini 
menjadi bukti bahwa adanya dukungan penuh dari Pemerintah Kota Bima terkait pengembangan pariwisata tersebut.

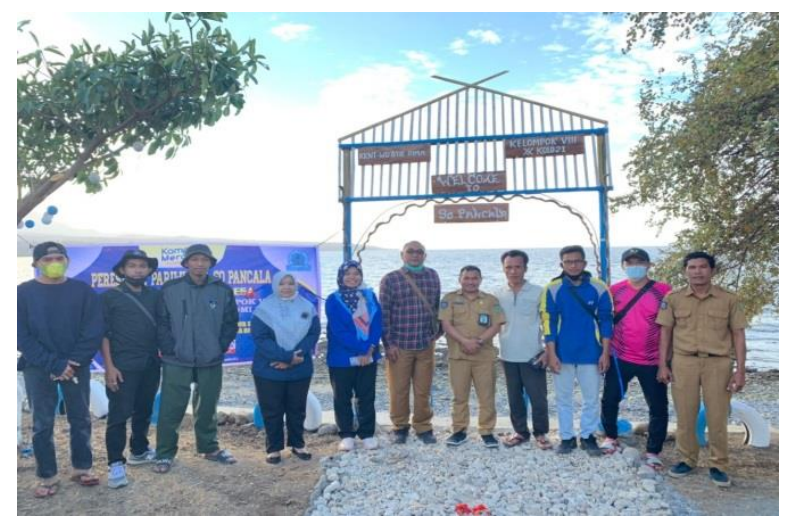

Gambar 5 Dokumentasi peresmian wisata pantai So pancala

\section{$\underline{\text { Kesimpulan }}$}

Setelah pelaksanaan kegiatan Pengabdian Kepada Masyarakat (PKM) ini, Kelurahan Kolo Kota Bima lebih mampu memaksimalkan potensi wisata yang ada, meskipun sebelumnya sudah banyak tempat wisata yang lebih dulu di kenal di sepanjang pantai. Adanya sarana pendukung seperti ayunan, tempat duduk, tempat sampah dan spotfoto akan lebih menarik wisatawan untuk berkunjung di pantai So Pancala. Jadi secara tidak langsung tujuan utama yang ingin di capai dari kegiatan pengabdian ini yaitu adanya peningkatan TS (Tourism Sector) dan ES (Economic Sector) akan terlaksana dengan baik. Kelengkapan sarana pendukung jelas akan meningkatkan jumlah pengunjung di tempat wisata dan secara langsung juga akan meningkatkan pendapatan ekonomi masyarakat dari banyaknya pengunjung di tempat wisata.

\section{$\underline{\text { Ucapan Terimakasih }}$}

1. Kepada Pimpinan STIE BIMA yang telah memberikan kesempatan kepada tim untuk melakukan pengabdian.

2. Jajaran pemerintahan dan seluruh warga Kelurahan Kolo Kota Bima yang sudah banyak membantu demi terlaksananya kegiatan pengabdian ini dengan baik.

3. Dosen dan mahasiswa KKN STIE BIMA yang membantu melakukan survei serta fasilitas saat melakukan kegiatan ini.

\section{Daftar Pustaka}

Aboe, R. M., \& Ibrahim, M. (2019). PENGEMBANGAN COMMUNITY-BASED TOURISM ( PARIWISATA BERBASIS MASYARAKAT) DI KAWASAN EKOWISATA PANTAI KASTELA Pada kegiatan PKM ini berbasis Program Kemitraan dimana Universitas Khairun sebagai. 2(1), 4553.

Pitana, I. G., \& Diarta, surya I. ketut. (2009). Pengantar Ilmu Pariwisata. Andi.

Suherlan, A. (2014). Analisis Karakteristik, Perilaku, dan Motivasi Perjalanan Wisatawan Asal Sulawesi Utara ke Jakarta. Esensi: Jurnal Bisnis Dan Manajemen, 4(3), 16-36.

Undang-Undang Otonomi Daerah. (2014). 